\title{
APLICAÇÃO DE GEOFíSICA COMO SUBSÍDIO PARA ESTUdOS DE ARQUEOLOGIA DO LIXO
}

\author{
Marcia Hatae \\ Orientador: Dr. Vagner Roberto Elis (IAG-USP) \\ 60 p. - Dissertação (Mestrado) - Defesa 10.06.2005
}

\begin{abstract}
RESUMO. 0 principal objetivo deste trabalho consistiu na aplicação do caminhamento eletromagnético e sondagens elétricas verticais (SEVs) numa área de disposição de resíduos sólidos (Lixão de Mogi das Cruzes) para a caracterização do local, principalmente quanto a existência e espessura dos resíduos sólidos. Como a área de estudo trata-se de um depósito de resíduos sem controle técnico e/ou histórico, a geofísica torna-se uma importante ferramenta para estudar e auxiliar na definição da estrutura do depósito. Essa caracterização visa fornecer subsídios para futuras escavações e estudos dos tipos de materiais, dentro da garbologia, novo ramo de pesquisa desenvolvido dentro da arqueologia que estuda os resíduos de uma população como meio para obter informações sobre seus hábitos e costumes. Este trabalho foi desenvolvido em conjunto com o MAE/USP, onde os levantamentos de geofísica visaram dar suporte a pesquisa de garbologia na área conhecida como Lixão de Mogi das Cruzes. Foram realizados levantamentos com 0 equipamento EM-34, 11 linhas de ensaio, o que possibilitou construir mapas de condutividade aparente para caracterizar de maneira geral o local de pesquisa, de modo a poder escolher as regiões de maior interesse para escavações por parte da equipe de garbologia. Posteriormente foi realizada uma segunda etapa de campo, na qual se utilizou sondagens elétricas verticais, cujo objetivo foi realizar um estudo mais detalhado de modo a encontrar áreas com maior coluna de lixo e nível da água mais profundo. Os levantamentos geofísicos forneceram, dessa forma, informações para a equipe de garbologia racionalizar o programa de escavações, diminuindo custos e tempo de trabalho, além de permitir uma boa amostragem do material depositado ao longo dos anos em que o local esteve em atividade.
\end{abstract}

ABSTRACT. The fundamental objective of the present work is to apply the electromagnetic (EM) profiling and the vertical electric sounding (VES s) to detail the main characteristics of a solid waste deposit (lixão de Mogi das Cruzes), and, basically, to determine either the existence and the thickness of the waste layers. As the studied area is categorized to be a solid waste deposit out of technical control and without historical registers, geophysics becomes an important tool to study and to define the structure of the deposit. Such objective is concentrated, in the present days, in offering subsidies for future excavations and studies of the types of materials, and to develop a new branch of geophysical research that deals, in collaboration with Archeology, with the study of the residues of ancient civilizations to get information about their habits and costumes. This work was developed in cooperation with MAE/USP, where the geophysical surveys had, as an objective, to give support to the garbology studies over the area of the deposit of Mogi das Cruzes. The EM-34 instrument was used to perform the geophysical surveys over eleven (11) profiles, which helped creating maps of the apparent conductivity, that characterize the studied area, giving a clear image about the areas of interest by excavations. A new step was performed successively, using the vertical electric sounding (VES s) to detail the chosen areas by EM-34, giving information about the points with thicker columns of waste of garbage and the deepest water-table founded over the area. Thereby, these geophysical surveys covered sufficiently the needed information by the excavation team, saving time and costs and permitting a good sampling of the deposited materials through over the years during which the area kept in activity. 